\title{
Awareness about Consequence of Teenage Pregnancy
}

\author{
Siddharth A.R. ${ }^{1}$, N. Hephzibah Kirubamani ${ }^{2}$ \\ $12^{\text {nd }}$ Year MBBS Student, Saveetha Medical College, Chennai, Tamilnadu, India. \\ ${ }^{2}$ Professor, Department of Obstetrics and Gynaecology, Saveetha Medical College and Hospital, Chennai, Tamilnadu. \\ India.
}

\section{ABSTRACT}

\section{BACKGROUND}

In a developing country like India, due to certain traditional customs, there are girls who become pregnant due to early marriage. There are multiple complications which could occur to the mother who has become pregnant at an adolescent age and to the foetus too. Various factors like educational status, religion, marital status, occupation, and type of family have an influence on this awareness. It also depends on the source of knowledge, respondents age of getting pregnant, knowledge about the consequences and the attitude and practice towards pregnancy.

\section{METHODS}

A cross-sectional study was conducted in the Department of Obstetrics and Gynaecology, Saveetha Medical College and Hospital, Chennai. A total of 122 women were included in the study. After institutional ethical clearance and after informed consent, women between the age of 23 years and 35 years and from both urban and rural background were interviewed with semi structured questions. Women who did not fall in this age group, women with psychiatric illness and not able to communicate, were excluded from the study.

\section{RESULTS}

Of the 122 participants in the study the maximum participants were in the age group of $23-27(80.32 \%)$ followed by $28-31$ years age group $(14.75 \%)$. The respondents' maximum source of information regarding awareness and consequences of adolescent pregnancy was from friends and peers (30.32\%). The most common cause for reduced adolescent pregnancy awareness was found to be lack of formal education (91\%). Most of the respondents felt that they would allow the girl to make her choice $(97 \%)$ whether to continue her pregnancy or not.

\section{CONCLUSIONS}

Awareness about the consequences of adolescent pregnancy was more among women who had formal school education and the source of information was mostly from the radio. The knowledge about consequences of adolescence pregnancy should be brought about by school education and by way of mass media propaganda.

\section{KEY WORDS}

Adolescent Pregnancy, Awareness, Risks of Adolescent Pregnancy, Risk to Mother and Child in Adolescent Pregnancy, Attitude and Practice Regarding Adolescent Pregnancy

\section{Corresponding Author:} Dr. N. Hephzibah Kirubamani, Professor,

Department of Obstetrics and Gynaecology, Saveetha Medical College and Hospital, Chennai, Tamilnadu, India.

E-mail: hepsi1002@yahoo.co.in

DOI: $10.14260 /$ jemds/2019/581

Financial or Other Competing Interests: None.

How to Cite This Article: Siddharth AR, Kirubamani NH. Awareness about consequence of teenage pregnancy. J. Evolution Med. Dent. Sci. 2019;8(34):26722676, DOI: 10.14260/jemds/2019/581

Submission 27-06-2019,

Peer Review 10-08-2019,

Acceptance 17-08-2019,

Published 26-08-2019. 


\section{BACKGROUND}

Adolescence is a phase of transition of physical and mental maturation and development that includes the biological, social and psychological parameters. It is between $10-19$ years of age as per The World Health Organization (WHO). Adolescent pregnancy has posed several obstetric and neonatal problems that have developed due to immaturity, unintended pregnancy, inadequate perinatal care, poor maternal nutrition and stress.(1) Socio-economic, cultural, geographic and racial factors also play a very important role in teenage pregnancy.(2) The problem of teenage pregnancy is very much prevalent as child marriages are still prevalent in Indian community.(3)Early marriage and confinement are contributing factors to high maternal, perinatal morbidity and mortality.

It is well known that in developing countries like India due to certain traditional societies, women still get married at an early age prior to the legal age constituted by the constitution (18 years). Hence these children become pregnant at an early age (Adolescence). When women are well educated, they bear a child at a much later age.(4) Hence childbearing is inversely proportional to the educational status. The factors which lead to early childbearing are lesser educational status, lower socio-economic status, ethnicity, religion, family structure and cultural background etc.(5)

Early marriages and having a child lead to lower level of women's autonomy and also has health hazards for the women and their children. It has been known that a girl who bears a child between 15 to 19 years of age carries a 2 fold risk of dying during pregnancy compared to a women who is above 20 years. ${ }^{(6)}$ The other issues associated with adolescence pregnancy are School drop-out, premature infant death, and small for date. (7)

These adolescent pregnant girls also undergo health risks such as unsafe abortions and its complications, pregnancy induced hypertension, anaemia, puerperal sepsis, tearing of the vagina, fistula, mental disorders due to physiological and psychological immaturity.(8)

In a study done by Sushila Devi Bhandari regarding the "Awareness on Consequences of Teenage Pregnancy among adolescent" (9) at Ampipal, it was concluded that more than half of the respondents had adequate knowledge about the consequences of teenage pregnancy to mother and baby and there is a relation between knowledge regarding the consequences of teenage pregnancy and education level.

We wanted to determine the awareness and knowledge among women about the consequences of adolescent pregnancy.

\section{METHODS}

A cross-sectional study was conducted in Saveetha Medical College and Hospital, Obstetrics \& Gynaecology Department Chennai among 122 women between 20-60 years attending outpatient department. After Institutional Ethical Clearance Interview was conducted after informed consent with semi structured questions including general and specific questions, regarding awareness about the consequences of adolescent pregnancy. Women with acute illness, psychiatric illness those who are not willing to participate in the study were excluded.

\section{Statistical Analysis}

The sample size calculation was done with reference to the article 'Awareness on consequences of teenage pregnancy among adolescent at Ampipal VDC, Gorkha' by Sushila Devi Bhandari in which the knowledge about the Cephalo pelvic disproportion was found to be the least (44\%). Based on this, the sample size of 122 was calculated with relative precision of $20 \%$ and alpha error of $3 \%$. After obtaining the data, it was entered in excel spreadsheet and was analysed using SPSS software and frequencies and percentages were obtained.

\section{RESULTS}

\section{Age Group}

In total, 122 women were studied, ranging from age group of 20 to 60 years 60 participants (49.17\%) were between the age group of 20-29 years; 39 participants (31.96\%) were between the age group of $30-39 ; 19$ participants (15.57\%) were between the age group of $40-49$; 4 participants $(3.27 \%)$ were between the age group of 50-60.

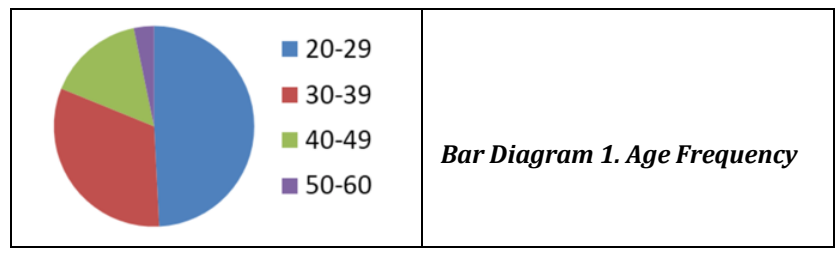

\section{Educational Status}

Out of 122 participants, 32 participants (26.22\%) did not have any formal education; 17 participants (13.93\%) had completed their primary schooling (1-8 class); 43 participants (35.2\%) had completed their secondary schooling (9-10 class); 9 participants (7.37\%) had completed their higher secondary schooling (11-12 class) and 21 participants (17.21\%) had completed their college education.
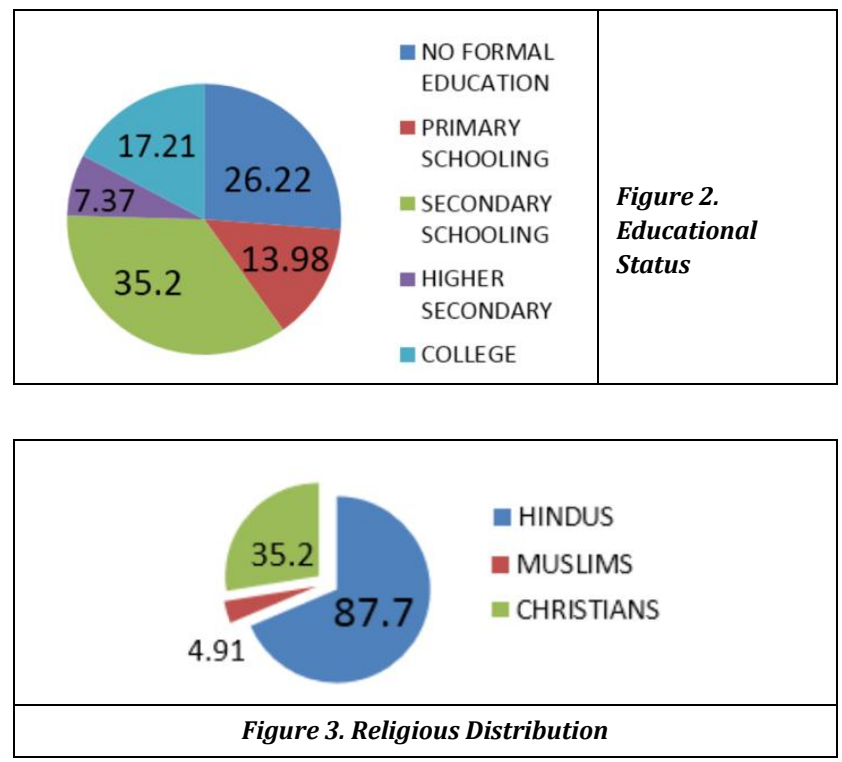


\section{Religious Distribution}

Out of the 122 participants, 107 participants (87.70\%) were Hindus; 6 participants (4.91\%) were Muslims and 9 participants $(7.37 \%)$ were Christians. All the 4 participants who said that it was a custom in their family to get married at an early age were Muslims.

\section{Marital Status}

Out of the 122 participants, 98 participants (80.32\%) were married and 24 participants (19.67\%) were unmarried. Many participants among the 98 married participants said that they were married at an adolescent age and majority of the 24 unmarried participants said that they did not want to get married at an adolescent age.

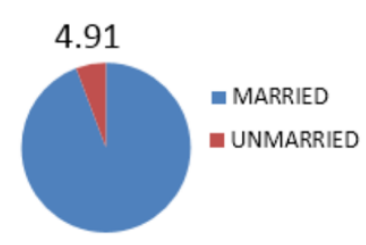

80.3

\section{Figure 4. Marital Status}

\section{Employment Status}

Out of the 122 participants, 4 participants $(3.27 \%)$ practiced agriculture; 16 participants $(13.11 \%)$ were employed in companies; 23 participants (18.85\%) were students; 77 participants $(63.11 \%)$ were homemakers and the other 2 participants $(1.53 \%)$ practiced other professions.

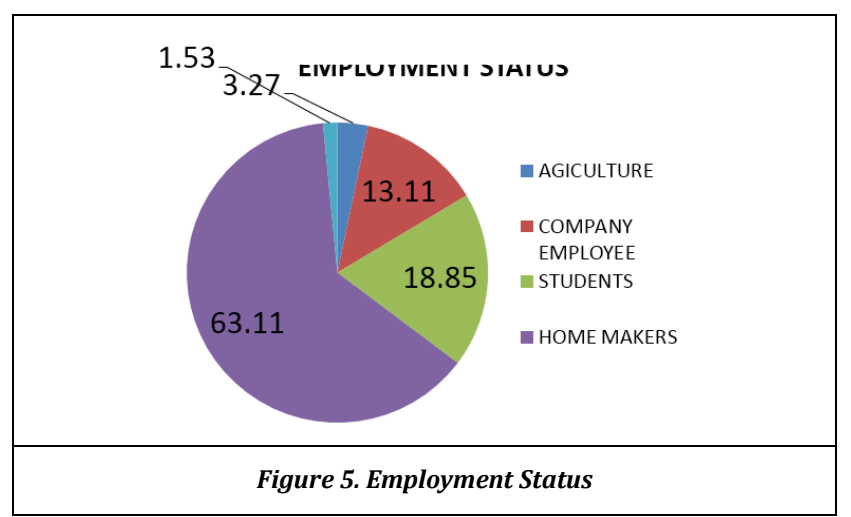

\section{Respondents' Knowledge Regarding Causes of Getting} Pregnant at an Early Age

No formal education was stated as one of the causes of getting pregnant at an early age by 111 participants (91\%); Marrying at an early age was stated as one of the causes of getting pregnant at an early age by 110 participants (90\%); Cultural background was stated as one of the causes of getting pregnant at an early age by 46 participants (38\%); Low knowledge about contraceptive use was stated as one of the causes of getting pregnant at an early age by 44 participants (36\%); Adolescent pregnancy in mother or sister was stated as one of the causes of getting pregnant at an early age by 45 participants (37\%); poor socio-economic status was stated as one of the causes of getting pregnant at an early age by 102 participants (84\%) and fear of sexual abuse (violence) among parents was stated as one of the causes of getting pregnant at an early age by 47 participants (39\%).

\begin{tabular}{|c|c|}
\hline Educational Status & Frequency \\
\hline No formal education & $91 \%$ \\
\hline Marrying at an early age & $90 \%$ \\
\hline Cultural backgrounds & $38 \%$ \\
\hline Low knowledge about contraceptive use & $36 \%$ \\
\hline Adolescent pregnancy in mother or sister & $37 \%$ \\
\hline Poor socio-economic status & $84 \%$ \\
\hline Fear of sexual abuse (violence) & $39 \%$ \\
\hline Figure 6. Respondents Knowledge Regarding Causes of Getting \\
Pregnant at an Early Age \\
\hline
\end{tabular}

Respondents' Knowledge Regarding Consequences of Adolescent Pregnancy to Mother and Baby

Only 32 participants ( $26 \%)$ were aware that abortion could be one of the consequences of adolescent pregnancy; Only 43 participants $(35 \%)$ were aware that anaemia in the mother could be one of the consequences of adolescent pregnancy; Only 19 participants (16\%) were aware that pregnancy induced hypertension in the mother could be one of the consequences of adolescent pregnancy; Only 24 participants (20\%) were aware that pre-term labour could be one of the consequences of delivery of adolescent pregnancy; Only 7 participants $(6 \%)$ were aware about instrumentation and operative delivery as one of the consequences of adolescent pregnancy; Only 23 participants (19\%) were aware that maternal mortality could be one of the consequences of adolescent pregnancy; Only 4 participants (3\%) were aware that obstructed labour due to Cephalo pelvic disproportion could be one of the consequences of adolescent pregnancy.

\begin{tabular}{|c|c|c|c|}
\hline $\begin{array}{c}\text { Sl. } \\
\text { No. }\end{array}$ & Consequences to Mother and Child & $\begin{array}{c}\text { Frequency } \\
\text { (Aware) }\end{array}$ & $\begin{array}{c}\text { Percentage } \\
\text { (Aware) }\end{array}$ \\
\hline 1 & Abortion & 32 & $26 \%$ \\
\hline 2 & Anaemia & 43 & $35 \%$ \\
\hline 3 & Pregnancy induced hypertension & 19 & $16 \%$ \\
\hline 4 & Pre-term labour & 24 & $20 \%$ \\
\hline 5 & Instrumentation and forceps delivery & 7 & $6 \%$ \\
\hline 6 & Maternal mortality & 23 & $19 \%$ \\
\hline 7 & Obstructed labour due to cephalo pelvic & 4 & $3 \%$ \\
\hline 8 & disproportion & 18 & $15 \%$ \\
\hline 9 & Neo natal death & 21 & $17 \%$ \\
\hline 10 & Pre-term delivery & 5 & $4 \%$ \\
\hline 11 & Birth asphyxia & 16 & $13 \%$ \\
\hline \multicolumn{3}{|c|}{ Figure 7. Respondent's Knowledge Regarding Consequences of } \\
\hline \multicolumn{3}{|c|}{ Adolescent Pregnancy to Mother and Baby } \\
\hline
\end{tabular}

Further, only 18 participants (15\%) were aware that neonatal death could be one of the consequences of adolescent pregnancy; Only 21 participants (17\%) were aware that preterm delivery could be one of the consequences of adolescent pregnancy; Only 5 participants (4\%) were aware that Birth Asphyxia in the child could be one of the consequences of adolescent pregnancy; Only 16 participants (13\%) were aware that low birth weight- IUGR could be one of the consequences of adolescent pregnancy.

\begin{tabular}{|c|c|c|c|}
\hline $\begin{array}{c}\text { Sl. } \\
\text { No. }\end{array}$ & Attitude/Practice & $\begin{array}{c}\text { Frequency- } \\
\text { Yes }\end{array}$ & $\begin{array}{c}\text { Frequency- } \\
\text { No }\end{array}$ \\
\hline 1 & $\begin{array}{c}\text { Will you accept your family girl to get married } \\
\text { at an adolescent age? }\end{array}$ & $\begin{array}{c}78 \%(97 \\
\text { participants) }\end{array}$ & $\begin{array}{c}22 \%(25 \\
\text { participants })\end{array}$ \\
\hline 2 & $\begin{array}{c}\text { Will you allow your family member to have } \\
\text { adolescent pregnancy? }\end{array}$ & $\begin{array}{c}97 \%(118 \\
\text { participants) }\end{array}$ & $\begin{array}{c}3 \%(4 \\
\text { participants })\end{array}$ \\
\hline 3 & $\begin{array}{c}\text { Will you allow an adolescent pregnant girl to } \\
\text { continue her pregnancy? }\end{array}$ & $\begin{array}{c}96 \%(117 \\
\text { participants) }\end{array}$ & $\begin{array}{c}4 \%(5 \\
\text { participants })\end{array}$ \\
\hline 4 & $\begin{array}{c}\text { Is it a custom in your family to get married at an } \\
\text { adolescent age? }\end{array}$ & $\begin{array}{c}3 \%(4 \\
\text { participants) }\end{array}$ & $\begin{array}{c}3 \%(4 \\
\text { participants })\end{array}$ \\
\hline \multicolumn{3}{|c|}{ Figure 8. Attitude and Practice towards Adolescent Pregnancy } \\
\hline
\end{tabular}




\section{Respondents' Knowledge Regarding Source of Information of Adolescent Pregnancy}

Television was the source of knowledge for about 33 participants (27.04\%); Magazines were the source of knowledge for about 29 participants $(23.77 \%)$; Radio was the source of knowledge for about 37 participants (30.32\%); Friends and peers were the source of knowledge for about 18 participants (14.75\%); and for the other 5 participants $(4.09 \%)$ it was from the Other sources (Books, Sex education, etc.)

\begin{tabular}{|c|c|}
\hline \multicolumn{2}{|c|}{ Respondents Knowledge Regarding Source of Information } \\
\hline Television & $27.04 \%$ \\
\hline Magazines & $23.77 \%$ \\
\hline Radio & $30.32 \%$ \\
\hline Friends and peers & $14.75 \%$ \\
\hline Other sources & $4.09 \%$ \\
\hline Figure 9. Respondents Knowledge Regarding Source of Information \\
of Adolescent Pregnancy \\
\hline
\end{tabular}

\section{DISCUSSION}

In the study regarding the awareness about the consequences of adolescent pregnancy, regarding demographics the maximum participants fell in the age group of ranging from 20 to 60 years, 60 participants $(49.17 \%)$ followed by 39 participants $(31.96 \%)$ between $30-39$ years age group whereas in the study by Vadivukakkarasi Ramananadian et al(10) the study population was maximum in the 13 to 15 year age group: $53.12 \%$.

In the study with regard to the educational status about $35.2 \%$ had done secondary school education and the least being higher school education of $7.37 \%$. Study done by Sushila Devi Bhandari et al ${ }^{(4)}$ also had almost a similar percent of educational status of $34 \%$ - secondary school and the least in that that studies being $10 \%$ who could read \& write only.

Most of the participants of our study group belonged to Hinduism: $87.7 \%$ and Christianity was the second being $7.37 \%$, which was similar to Sushila Devi Bhandari(11) study with $95 \%$ Hindus. The participants of our study group about $80.32 \%$ were married, which was in contrast to the study by Vadivukakkarasi Ramananadian et al where all $100 \%$ were unmarried. Majority of the 24 unmarried participants said that they did not want to get married at an adolescent age. Maximum participants in our study were housewives (63.11\%), whereas in the study by Sushila Devi Bhandari most of them were students $78 \%$ The types of family status with regarding to our study were mostly single, about $79.5 \%$, whereas in the study by Sushila Devi Bhandari most of the participants were of the joint family type: $54 \%$.

In our study group the source of knowledge regarding the awareness about the consequences of adolescent pregnancy was maximum from the friends and peers: $30.32 \%$, which was similar to the study of Sushila Devi Bhandari which showed about $33 \%$

In our study, it was observed that illiteracy: $91 \%$ and marrying at an early age: $90 \%$ were the most common reasons of respondents getting pregnant at an early age which was similar to the study done by Sushila Devi and Bhandari $92 \%$ \& $90 \%$ respectively. In our study we also observe that there is a correlation between the educational status and awareness about the complications of adolescent pregnancy. We observe that maximum awareness (33\%) about the consequences of adolescent pregnancy is among the women who have either completed or pursuing a course in a college. We also observe that the least awareness about the complications of adolescent pregnancy was in women who did not have any formal education.

In our study we also observe a correlation between employment status and awareness about the consequences of adolescent pregnancy. Maximum awareness (13\%) about the consequences of adolescent pregnancy was present in company employees and a major proportion of them stated that their exposure to the various difficulties in life and getting to know a variety of people and their views at their working place has helped them gain the awareness. Also, we find that the least awareness (4\%) about the consequences of adolescent pregnancy was seen in women who engaged in agricultural work as labourers.

In our study it was observed that low knowledge about contraceptive use $36 \%$ was one of the common causes of getting pregnant at an early age and Oringanje C.et al.'s study shows a similar result where close to about $50 \%$ of the study population stated a similar reason. A study by Krugu JK shows similarity in the range of results, where lack of knowledge regarding use of condoms was stated as a reason of getting pregnant at an early age.

Our study observed that anaemia (35\%) was the most the common consequences known and the least was obstructed labour due to Cephalo-pelvic disproportion (3\%), whereas in the study done by Sushila Devi Bhandari it was observed that the most and least consequences known were maternal death (84\%) and Eclampsia (50\%).

From the result of the study we can also understand that a major proportion (78\%) of the study population is still ready to allow a girl from their family to get married at an adolescent age. Many women said that they wanted to complete their responsibilities and hence wanted their daughters or the girls of their family to get married at a young age. Further about $97 \%$ of the women in the study population stated that they would not mind if the adolescent girl, who got married, gets pregnant and further added to it by saying that they would not encourage the termination of the pregnancy and would let the girl to continue her pregnancy.

In our study, regarding knowledge about the consequences to the baby in adolescent pregnancy, study subjects had the most knowledge regarding preterm delivery and they had the least knowledge regarding asphyxia. The study done by Sushila Devi Bhandari observed that Neonatal death being the commonest and Cephalopelvic disproportion was the least.

When we asked the participants of the study for their suggestions on how they feel that the awareness about the consequences of adolescent pregnancy could be developed, a major proportion among them stated that outreach and community wide campaigns about the consequences of adolescent pregnancy could be encouraged, while others stated that adolescent health education, youth development programmes, involvement of the members of the family and caring adults were also an essential part to promote the awareness about the consequences of adolescent pregnancy not only in adolescent children but in their family members as well. 
Hence we understand that it is highly essential for a combined participation of teachers, elders, doctors, social activists and others belonging to teaching, health and health allied professions to take it up as their moral responsibility to plant the seed about the consequences of adolescent marriage and pregnancy in the young minds and the other members of the society, so that everyone gets a psychologically, financially, physically and morally a better and a happy life.

\section{CONCLUSIONS}

Awareness about the consequences of adolescent pregnancy was more among women who had formal education and in those who were employed and had an exposure to what is happening around them in the society. The source of information regarding the same for maximum number of participants was from the radio. The knowledge on the dreaded complications and consequences were not sufficient and it should be brought about by adolescent school education and by way of mass media propaganda.

\section{ACKNOWLEDGEMENT}

I would like to thank the Director of Saveetha Medical College and Hospital, Prof. Saveetha Rajesh for the support and encouragement, Dean of Saveetha Medical College and Hospital, Dr. J. Damodharan, for permitting me to conduct the study. I would like to thank the participants of the study.

\section{REFERENCES}

[1] Jacob A. A comprehensive textbook and midwifery. New Delhi: J P Brothers Medical Publishers 2012.

[2] WHO/Adolescent health-World Health Organization. A review.

http://www.who.int/topics/adolescent_health/en/
[3] Carmen Solomon-Fears. Teenage Pregnancy Prevention: Statistics and Programs. Congressional Research Service. A review. January 15, 2016. https://fas.org/sgp/crs/misc/RS20301.pdf

[4] Adolescent Pregnancy / UNFPA. A review. http://www.unfpa.org/adolescent-pregnancy

[5] Hadley A. Young mothers face stigma and abuse, say charities. A review. http://www.bbc.co.uk/newsbeat/article/26326035/you ng-mothers-face-stigma-and-abuse-say-charities

[6] Brown M. The effectiveness of a teen pregnancy prevention program that offers special benefits for pregnant and parenting teens: a qualitative study. A review.

http://digitalcommons.liberty.edu/cgi/viewcontent.cgi? article $=1770$ and context $=$ doctoral

[7] Loto OM, Ezechi OC, Kalu BK, et al. Poor obstetric performance of teenagers: is it age - or quality of carerelated? Journal of Obstetrics and Gynaecology 2004;24(4):395-8.

[8] Oringanje C, Meremikwu MM, Eko H, et al. Interventions for preventing unintended pregnancies among adolescents (review). 2010. http://www.gfmer.ch/SRHCourse-2010/adolescent-sexual-reproductivehealth/pdf/Cochrane-review-prevention-unintendedpregnancies-2009.pdf

[9] Pranay G, Sunita S, Rahul F. A study of teenage pregnancies in rural area. Indian Journal of Applied Research 2014;4(5):506-7. https://www.worldwidejournals.com/indian-journal-ofapplied-research-

IJAR)/file.php?val=May_2014_1398966915_e9548_158.p $\mathrm{df}$

[10] Ramanadin VP. Knowledge on teenage pregnancy. Pondicherry Journal of Nursing 2012;5(3).

[11] Koranne PS, Wahane AR. Pregnancy in adolescence: is it really a concern? Journal of Evolution of Medical and Dental Sciences 2014;3(28):7659-68. 